\title{
Correction to: An assessment of rainfall-induced land degradation condition using Erosivity Density (ED) and heatmap method for Urmodi River watershed of Maharashtra, India
}

\author{
Wasim A. Bagwan ${ }^{1}$ (1) $\cdot$ Ravindra S. Gavali ${ }^{2}$
}

Published online: 14 October 2020

(c) Springer Nature Switzerland AG 2020

\section{Correction to: \\ Journal of Sedimentary Environments (2020) 5:279-292 https://doi.org/10.1007/s43217-020-00014-7}

After publication of this work, we noted that we failed to include the coauthor. The coauthor is Ravindra S. Gavali. We apologize for the oversight.

Publisher's Note Springer Nature remains neutral with regard to jurisdictional claims in published maps and institutional affiliations.

The original article can be found online at https://doi.org/10.1007/ s43217-020-00014-7.

\section{Wasim A. Bagwan}

wasim.bagwan16@gmail.com

1 Department of Environmental Science, School of Earth

Sciences, Punyashlok Ahilyadevi Holkar Solapur University,

Solapur 413255, India

2 Centre for Natural Resource Management (CNRM),

National Institute of Rural Development and Panchayati Raj

(NIRDPR), Hyderabad 500030, India 